understanding the peoples of Southern Asiahave been published by the UNIVERSITY of ILLINOIS graduate school of library science.

Case studies are provided in Proceedings of the 1966 Clinic on Library Applications of Data Processing, edited by Herbert Goldhor. It includes progress reports from Massachusetts Institute of Technology, Johns Hopkins University, University of California at Los Angeles, Texas A\&M, and Chemical Abstracts Service. Donald L. Bitzer, Elisabeth R. Lyman and John A. Easley, Jr. discuss "The Uses of PLATO: A Computer Controlled Teaching System." James Krikelas, a U of I doctoral student, compiled a bibliography of case reports of library applications of data processing which was published as part of the proceedings.

Federal Legislation for Libraries, edited by Winifred Ladley, consists of papers presented at the thirteenth annual Allerton Park Institute, Nov. 6-9. They cover the impact of federal legislation on school, public, academic, governmental and special libraries, and on library education. The publication also includes a paper on "The Federal Government as a Partner" by Dean Orville G. Bentley, U of I College of Agriculture.

Number 81 in the library school's Occasional Paper series is Understanding the Peoples of Southern Asia: A Bibliographical Essay by Cecil Hobbs, head of the South Asia section of the Library of Congress. It costs $\$ 1$ and can be ordered from the library school publications office, 435 Library, Urbana.

Both proceedings publications are distributed by the Illini Union Bookstore, Champaign, for $\$ 3$ in cloth and $\$ 2$ in paperback.

The Franklin Institute library announces publication of Current Periodicals 1966, a list of 3,148 serial titles in the physical sciences and technology currently received by the library. Two thirds of the publications are foreign periodicals, including the principal journals from Russia, China, and Japan. Current Periodicals 1966, is the result of the library's Serials Computer Project. The list includes journals, annuals, continuations, and government publications received by the library as of Tanuary 1967. Current Periodicals 1966, may be obtained through the library's Photoduplication Service at a price of $\$ 9$ per copy. The full address is: The Franklin Institute Library, Photoduplication Service, 20th and The Parkway, Philadelphia, Pennsylvania 19103.

A semi-annual journal of experimentation in librarianship, entitled Progressive Librarian, is intended to "provide a medium for analytical discussions of newer ideas and practices in librarianship and related fields," according to an announcement by its managing editor, Sushil K. Jain, Regina Campus library, University of Saskatchewan. To be published twice a year, in July and December, the new journal "envisages a newer and active role of the librarian in public and academic communities."

The National Librany of Nigeria is pleased to announce the National Library Publication Series. Numbers 1-3 have been issued. (1) Special Libraries in Nigeria; (2) The Arts in Nigeria-a selected bibliography; and (3) 18th \& 19th Century Africana in the National Library. These publications are six-page folded pamphlets; others in the series may be more extensive. They are available from the $\mathrm{Na}$ tional Library on a prepaid subscription basis of $£ 110 \mathrm{~s}$, or $\$ 5.00$. It is expected that about six a year will be produced.

\section{FOREIGN AREA MATERIALS CENTER}

Representatives of eleven regional groupings of colleges and universities have announced the formation of a National Council for Foreign Area Materials. The Council will seek to meet the needs for teaching materials about foreign areas at the undergraduate level. Initial plans of the Council include support for the production and distribution of bibliographies, library acquisition guides, course syllabi, audio-visual materials, and reprints of out-ofprint materials appropriate for undergraduate programs. The Council hopes to identify priorities and to coordinate the production of materials to meet these needs on a nation-wide scale. The Council looks forward to working closely with scholarly groups, publishers, and other sources of materials in the United States and abroad and is already in close touch with such groups as the Association for Asian Studies.

The Council headquarters will be in New York. Further information may be obtained from the Foreign Area Materials Center, 33 West 42nd Street, New York, New York (212CH 4-8480).

Fred C. Cole, president of Washington and Lee University since 1959, has been elected to the presidency of the Council on Library Resources to succeed Verner W. Clapp in September. Dr. Cole's resignation from the university presidency was accepted by Washington and Lee trustees on May 20. He is chairman of the USOE Advisory Committee on Research. $\mathrm{Mr}$. Clapp, who is retiring, will continue with CLR until he is relieved by the new president. 